\title{
Students' mathematical reasoning ability in solving post-covid-19 PISA model math problems
}

\author{
Linda $^{\text {a, *, Ira Asyura }}{ }^{\text {b }}$ \\ Program Studi Pendidikan Matematika, STKIP Syekh Manshur \\ Jl. Raya Labuan Kilometer 5 Kadulisung, Pandeglang, Banten, 42253, Indonesia \\ E-mail: a linda@stkip.syekhmanshur.ac.id, bira_asyura@stkip.syekhmanshur.ac.id \\ *Corresponding Author
}

\begin{tabular}{|c|c|}
\hline ARTICLE INFO & ABSTRACT \\
\hline \multirow{5}{*}{$\begin{array}{l}\text { Article history } \\
\text { Received: } 25 \text { Oct. } 2021 \\
\text { Revised: } 16 \text { Nov. } 2021 \\
\text { Accepted: } 29 \text { Nov. } 2021 \\
\text { Keywords } \\
\text { Covid-19, mathematics, } \\
\text { PISA, reasoning ability }\end{array}$} & $\begin{array}{l}\text { This study aims to describe the reasoning abilities of high school students in } \\
\text { Pandeglang Regency, Indonesia in solving post-Covid-19 PISA model math } \\
\text { problems. The subjects of this study were } 80 \text { students of two state senior high } \\
\text { schools in Pandeglang Regency, Indonesia. The data collection used a written } \\
\text { test consisting of four description questions in the form of PISA model math }\end{array}$ \\
\hline & $\begin{array}{l}\text { questions (levels } 2,3,4, \text { and } 5 \text { ), and were through interviews and } \\
\text { documentation. The data analysis followed the steps of data reduction, data } \\
\text { presentation, and conclusion drawing. The results show that the reasoning } \\
\text { abilities of Pandeglang Regency high school students in post-Covid-19 are fair }\end{array}$ \\
\hline & $\begin{array}{l}\text { in following the rules of inference, checking the validity of arguments, proving, } \\
\text { drawing logical conclusions, using patterns, analyzing mathematical situations, } \\
\text { and generalizing. However, the reasoning abilities were very poor in providing } \\
\text { explanations of models, facts, characteristics, and relationships; constructing } \\
\text { valid arguments; and studying conjectures. Thus, it can be concluded that the } \\
\text { mathematical reasoning ability of Pandeglang Regency senior high school } \\
\text { students is poor when measured using the PISA Post-Covid-19 model of } \\
\text { mathematics questions. }\end{array}$ \\
\hline & This is an open access article under the CC-BY-SA license. \\
\hline & (c) (i) () \\
\hline
\end{tabular}

How to Cite: Linda, L., \& Asyura, I. (2021). Students' mathematical reasoning ability in solving post-covid-19 PISA model math problems. Jurnal Riset Pendidikan Matematika, 8(2), $140-152$. https://doi.org/10.21831/jrpm.v8i2.44739

\section{INTRODUCTION}

Reasoning ability is one of the standard process components in NCTM (The National Council of Teachers of Mathematics) in addition to problem solving, representation, communication and connection skills. Mathematical reasoning is a thought process carried out by drawing conclusions (Anisah et al., 2011). Reasoning and mathematics are an inseparable unit because mathematical material is understood through reasoning (Sunardi \& Muslimin, 2019). Mathematical reasoning ability is very important in daily life because it can solve a problem in daily life both related to mathematics and others. PISA (Program for International Student Assessment) is a form of evaluation that measures skills and abilities designed for 15 year old students. PISA itself is a project of Organization for Economic Cooperation and Development (OECD) which was first conducted in 2000. The areas assessed in PISA are reading, mathematics, and science. Indonesia joined PISA in 2000. Indonesian students' mathematical ability based on the results of the PISA study shows that it is still relatively low. The results of the 2012 PISA study, Indonesia is at level 63 of 64 countries with an average score of 375 (OECD, 2014). In 2018 the results of the PISA study, Indonesia was at level 72 out of 78 countries with an average score of 379 math skills (Harususilo, 2019). According to NCTM, the ability to learn mathematics is problem solving, reasoning, communication, connection and representation (NCTM, 2000). In this study, reasoning is the main subject of the research. Mathematical reasoning ability is found in PISA model math problems. PISA model math problems emphasize more on what students can do to reflect and 
evaluate the material, not only to answer questions that have a single correct answer. Students are expected to have mathematical literacy skills, namely being able to analyze, reason, and communicate mathematical knowledge and skills effectively, and being able to solve and interpret mathematical solutions in various situations.

In 2020, all countries experienced the Covid 19 pandemic disaster, namely the 2019 corona virus disease outbreak. Indonesia is also an infected country, the first confirmation on March 2, 2020 was delivered by President Joko Widodo accompanied by the Minister of Health (Akbar, 2020). After the announcement, all activities of the Indonesian people were restricted, including schools from PAUD, $\mathrm{SD}, \mathrm{SMP} /$ equivalent, SMA/equivalent, and tertiary levels, and were transferred to learn at home using online learning media. Home learning is enforced until this pandemic ends. This learning activity is carried out from Sabang to Merauke, including in Pandeglang Regency. Pandeglang Regency is one of the regencies in Banten Province, Indonesia, with its capital city being Pandeglang. Schools in Pandeglang are also conducting online learning during Covid-19. There are 123 high schools in Pandeglang Regency, with details of 22 public schools and 101 private schools. It has been almost 1.5 years that online learning activities have been running and there are already graduates from the results of online learning activities. The results of these student graduates should be seen how students' abilities, especially in mathematics ons from online learning results after Covid-19.

Mathematics is one of the subjects that plays a very important role in education. Learning mathematics from an early age can train them in solving problems in daily life because learning mathematics can train children to be thorough, flexible, accurate, efficient, and precise (Linda, 2020). Another opinion related to mathematics is an important lesson in improving the quality of education because its role is quite relevant to the development of science and technology (Hasanah et al., 2019). Mathematics is an important subject in improving the quality of education because its role is quite relevant by using science and technology. Studying mathematics is a must, because learning this science has many benefits, namely it is needed in various fields, both in mathematics itself and in other fields. Mathematics not only meets the needs of the present but also meets the needs of the future. One of the five skills that must be possessed in learning mathematics is the ability to reason.

Mathematical reasoning ability is someone who is able to think analytically, tends to note patterns, structures, or regularities in real world situations, with intentional patterns or with a reason and they speculate and prove so that they can make decisions and conclusions (NCTM, 2000). The ability to reason is essential to understand mathematics, by developing ideas, exploring phenomena, justifying results, and using mathematical conjectures in all content with different expectations. Another opinion states the reasoning is the thinking process that connects facts or concepts to draw a conclusion (Ginting et al., 2018; Basra \& Fauzi, 2017; Wahyuni et al., 2019). In other words, mathematical reasoning ability is a thinking process that connects facts or concepts to draw conclusions. Mathematical reasoning is a process carried out to obtain a conclusion based on logical mathematical premises based on relevant facts and sources that are considered true (Hasanah et al., 2019). Based on the explanation of mathematics and mathematical reasoning, it can be concluded that mathematics and reasoning are interrelated, therefore there is reasoning ability in mathematics.

The fields assessed by PISA are reading, mathematics and science. In the field of mathematics, the purpose of the assessment consists of three interrelated aspects: (1) a mathematical process that describes what individuals do to relate the context of the problem to mathematics and solve the problems and abilities that underlie the process; (2) targeted math content for use in assessment items; (3) the context in which the assessment items are placed. Mathematical problems in the PISA model relates to mathematical literacy which consists of formulating situations mathematically, using mathematical concepts, facts, procedures, reasoning, interpreting, applying and evaluating mathematical results. In PISA there are seven foundations of mathematical ability, i.e.: (1) communication, (2) mathematising, (3) representation, (4) reasoning and argument, (5) devising strategies for solving problems, (6) using symbolic, formal and technical language and operations, and (7) using mathematical tools (OECD, 2013).

Several previous studies related to reasoning in this study, research conducted by Manalu et al. (2020) related to the mathematical reasoning ability of male and female students in working on PISA questions. The research related to PISA questions, namely research conducted by Usnul et al. (2019) developing PISA-equivalent mathematical reasoning skills using traditional Acehnese home contexts. In addition, research on the analysis of reasoning abilities for abstract algebra subjects shows that the 
results of reasoning abilities are in the low category (Agustyaningrum et al., 2019). There are other studies that apply mind mapping strategies to improve the mathematical reasoning abilities of high school students (Ayal et al., 2016). Research on mathematical modeling skills in solving PISA problems shows good results (Ambarita et al., 2018). From several studies that have been carried out, the difference between this study and other research is that this study looks at the mathematical reasoning abilities of students in Pandeglang Regency in solving post-Covid-19 PISA model math problems. The main reasons for conducting this research are (1) There is no overall research to determine the mathematical reasoning ability of high school students in Pandeglang Regency; (2) For math problems with the PISA model, there is no research in Pandeglang Regency that uses this model; (3) There is no research to see the reasoning ability of Pandeglang Regency High School students after Covid-19 which during the pandemic students study online.

Therefore, based on the background of the problem and the theoretical study that has been stated previously, it is important to investigate, how the mathematical reasoning ability of Pandeglang Regency High School students in solving PISA model math problems. The specific purpose of this study was to figure out how the reasoning abilities of Pandeglang Regency High School students in solving postCovid-19 PISA model math problems. The urgency of this research is that reasoning ability is closely related to logical, analytical, and critical thinking patterns. By knowing the reasoning ability of high school students in Pandeglang Regency, it can describe the condition of students in Pandeglang Regency have the ability to make decisions in daily problems excellent/good/fair/poor/very poor.

\section{METHOD}

The research is a descriptive qualitative research. The study was conducted to determine the mathematical reasoning ability of high school students in class X Pandeglang Regency in solving PISA model math problems. This research was conducted at SMA Negeri 1 Pandeglang and SMA Negeri 2 Pandeglang, Banten. The subjects of this study consisted of 40 students of class X SMA Negeri 1 Pandeglang and 40 students of class X SMA Negeri 2 Pandeglang. Hence, the total subject of class X SMA Pandeglang is 80 students who have heterogeneous academic abilities (low, medium, and high). Data collection techniques by means of tests, interviews, and documentation. Each test was carried out once in each school where the study was conducted. The interview was conducted once, namely interviewing the mathematics teacher of class $X$ at SMAN 1 Pandeglang and SMAN 2 Pandeglang regarding students' reasoning abilities. Documentation was conducted in every activity through photos, recordings, or videos. The test instrument used was 4 PISA model mathematical description questions (level 2, 3, 4, 5) related to mathematical reasoning abilities that had been validated by experts in the field of mathematics and tested on 29 students of class XI at SMAN 1 Pandeglang the results were valid. The results of the reliability test are $r_{\text {count }}=0.567$ and $r_{\text {table }}=0.367$, so $r_{\text {count }}>r_{\text {table }}$ it means that the test instrument in this study is reliable. The interview instrument in this study was to make several questions addressed to the mathematics teacher of class X SMA related to students' reasoning abilities and had been validated by Indonesian language experts. After getting test results, interviews with teachers, and documentation results. Researchers conducted data analysis by means of data reduction, data presentation and drawing conclusions. Data validation uses source triangulation, namely matching student test results, interview results and documentation results. In this study, researchers used indicators of mathematical reasoning according to (NCTM, 2000), can be seen in Table 1.

Table 1. Mathematical reasoning indicator

\begin{tabular}{l} 
Reasoning indicator according to NCTM \\
\hline 1) Draw logical conclusions; \\
2) Providing an explanation of the model, facts, properties, and relationships/patterns; \\
3) Estimating the answer and the solution process; \\
4) Using patterns and relationships to analyze mathematical situations or make analogies, generalizations; \\
5) Developing and study conjectures (allegations); \\
6) Formulating an example opponent; \\
7) Following the rules of inference, checking the validity of arguments, proving; \\
8) Composing valid arguments; \\
9) Developing direct, indirect, and use mathematical induction proofs.
\end{tabular}


The level of students' mathematical ability in PISA questions are divided into six levels, level 6 being the higher level and level 1 being the lower. In this study, the level of students' mathematical abilities in the PISA math problems used were level 2, 3, 4, 5 (OECD, 2013), with the reasoning indicators in Table 1, and can be seen in Table 2.

Table 2. The level of students' mathematical ability in PISA questions and reasoning indicators

\begin{tabular}{|c|c|c|}
\hline Level & Math competence & Reasoning indicator \\
\hline 2 & $\begin{array}{l}\text { Students can interpret and recognize situations in } \\
\text { contexts that require direct inference. Students can sort } \\
\text { out relevant information from a single source and use a } \\
\text { single representation method. }\end{array}$ & $\begin{array}{l}\text { - Follow the rules of inference, } \\
\text { check the validity of } \\
\text { Arguments, prove. } \\
\text { - Draw logical conclusions. }\end{array}$ \\
\hline 3 & $\begin{array}{l}\text { Students can carry out procedures well, including } \\
\text { procedures that require sequential decisions. Students } \\
\text { can choose and apply simple problem solving } \\
\text { strategies. }\end{array}$ & $\begin{array}{l}\text { - Using patterns and } \\
\text { relationships to analyze } \\
\text { mathematical situations/make } \\
\text { analogies, generalize }\end{array}$ \\
\hline 4 & $\begin{array}{l}\text { Students can work effectively with models in concrete } \\
\text { but complex situations. Students can select and } \\
\text { integrate different representations, and relate them to } \\
\text { real situations. }\end{array}$ & $\begin{array}{l}\text { - Providing an explanation of } \\
\text { the model, facts, properties, } \\
\text { and relationships/patterns } \\
\text { - Composing valid arguments }\end{array}$ \\
\hline 5 & $\begin{array}{l}\text { Students can work with models for complex situations, } \\
\text { know the constraints faced, and make assumptions. } \\
\text { Students can select, compare, and evaluate strategies } \\
\text { for solving complex problems related to this model. }\end{array}$ & $\begin{array}{l}\text { - Developing and study } \\
\text { conjectures (allegations) }\end{array}$ \\
\hline
\end{tabular}

Scoring of students' mathematical reasoning abilities, using the rubric for assessing mathematical reasoning abilities developed by Thompson (Sulistiawati, 2014). Table 3 shown Mathematical reasoning assessment criteria.

Table 3. Mathematical reasoning assessment criteria

\begin{tabular}{cl}
\hline Score & Criteria \\
\hline 4 & Answers are substantially correct and complete \\
3 & Answer contains one significant error or omission \\
2 & Partially correct answers with one or more significant errors or omissions \\
1 & Some answers are incomplete but contain at least one correct argument \\
0 & Incorrect answer based on process or argument, or no response at all \\
\hline
\end{tabular}

After getting the test results of students' mathematical reasoning abilities in solving PISA math problems, then the student's test results were calculated the percentage of each student, then the average percentage of the overall mathematical reasoning ability of Pandeglang Regency students, and the percentage per indicator. From the results of these percentages can determine the criteria for reasoning ability, it can be seen in Table 4 the criteria for mathematical reasoning ability according to Arikunto \& Jabar (2018).

Table 4. Mathematical reasoning ability criteria

\begin{tabular}{cll}
\hline No. & Scale & Criteria \\
\hline 1. & $81 \%-100 \%$ & Excellent \\
2. & $61 \%-80 \%$ & Good \\
3. & $41 \%-60 \%$ & Fair \\
4. & $21 \%-40 \%$ & Poor \\
5. & $<21 \%$ & Very Poor \\
\hline
\end{tabular}




\section{RESULTS AND DISCUSSION}

After grade X students have conducted online learning for 1.5 years, there have been graduates from online learning outcomes and now in 2021 as of July 2021, Limited face-to-face learning has been implemented, so based on the results of the mathematical reasoning ability test in solving math problems with the PISA model on high school students in Pandeglang Regency, it shows that the average percentage of students' mathematical reasoning ability in solving post-Covid-19 PISA model math problems is $34 \%$, based on Table 4, the mathematical reasoning ability of Pandeglang Regency PostCovid-19 high school students is in the poor criteria. The percentage of the results of the mathematical reasoning ability test of high school students in Pandeglang Regency presented in Table 5.

Table 5. Percentage of students' mathematical reasoning ability test results

\begin{tabular}{ccccc}
\hline No. 1 & No. 2 & No. 3 & No. 4 & Average Percentage \\
\hline $55 \%$ & $52 \%$ & $12 \%$ & $16 \%$ & $34 \%$ \\
\hline
\end{tabular}

Question number 1 is a PISA Level 2 model of mathematics, mathematical competence at this level is that students can interpret and recognize situations in contexts that require direct inference. In accordance with the explanation in Table 2. The indicators of mathematical reasoning in question number 1 are following the rules of inference, checking the validity of arguments, proving and drawing logical conclusions. The following is the question number 1: "The management of the CAS Water Park Pandeglang amusement park stipulates that one ticket must be used to enter the four game areas with the following conditions: (1) The play areas that can be selected are swivel dragon, tourist train, roller coaster, ball bath , motor battery, haunted house, and adventure boat. (2) Ball bath, roller coaster, and spinning dragon cannot be taken in the same ticket. (3) The haunted house and adventurer boat must be taken but not on the same ticket. (4) Visitors who enter the haunted house must also choose a ball bath. (5) Visitors who enter the motor battery are not allowed to choose adventure boats. (6) If in a ticket the visitor chooses a motor battery, another game area that can be entered is..."

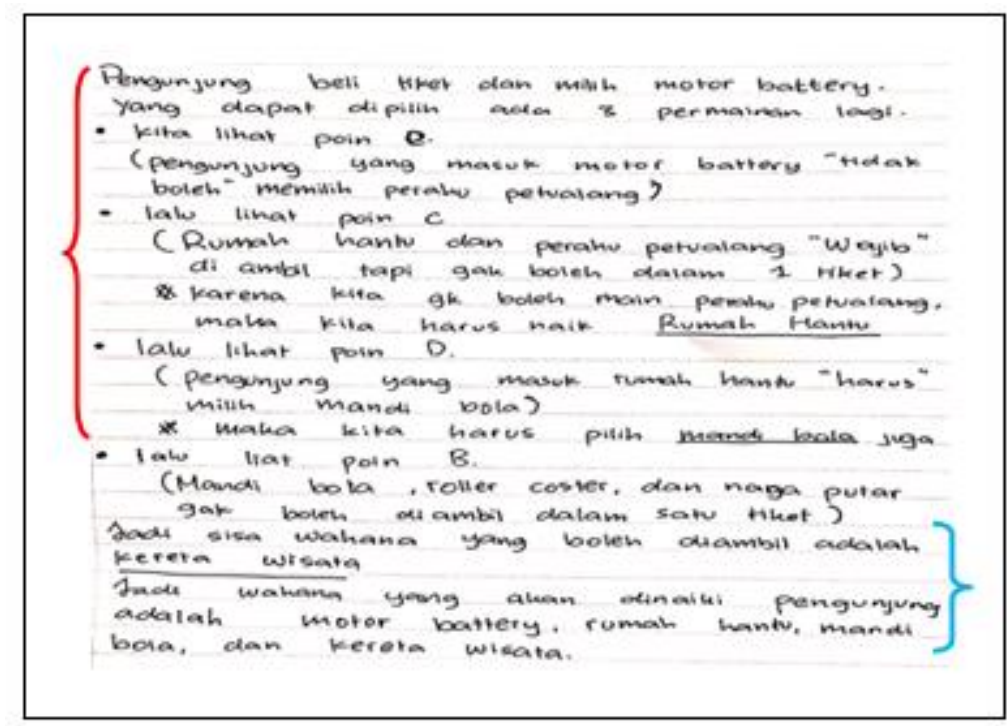

Figure 1. Example of students answering correctly No. 1

In question number 1 , out of 80 students there were 29 students or $36 \%$ who answered correctly. Figure 1 above is an example of a student's correct answer. In Figure 1 we can see, the student's mathematical reasoning ability on the indicators follows the rules of inference, checks the validity of arguments, proves and draws logical conclusions is good by getting a score of 4 according to Table 3 . Students follow the rules that already exist in the questions, check the validity In a detailed argument, students analyze the rules that exist in the questions, which can be seen in Figure 1 with a red mark. Then students prove and draw logical conclusions that the rest of the rides that can be taken are tourist trains so that students draw logical conclusions as a whole properly and correctly, it can be seen in Figure 1 with a blue mark. In question number 1, there were students who answered incorrectly, from 
80 students there were 51 students or $64 \%$. On average, students do not follow the rules that have been listed in the questions so that the answers are wrong, while students answer with the correct rules but in the final stage they make the wrong logical conclusions. The Figure 2 shows an example of a student who answered incorrectly.

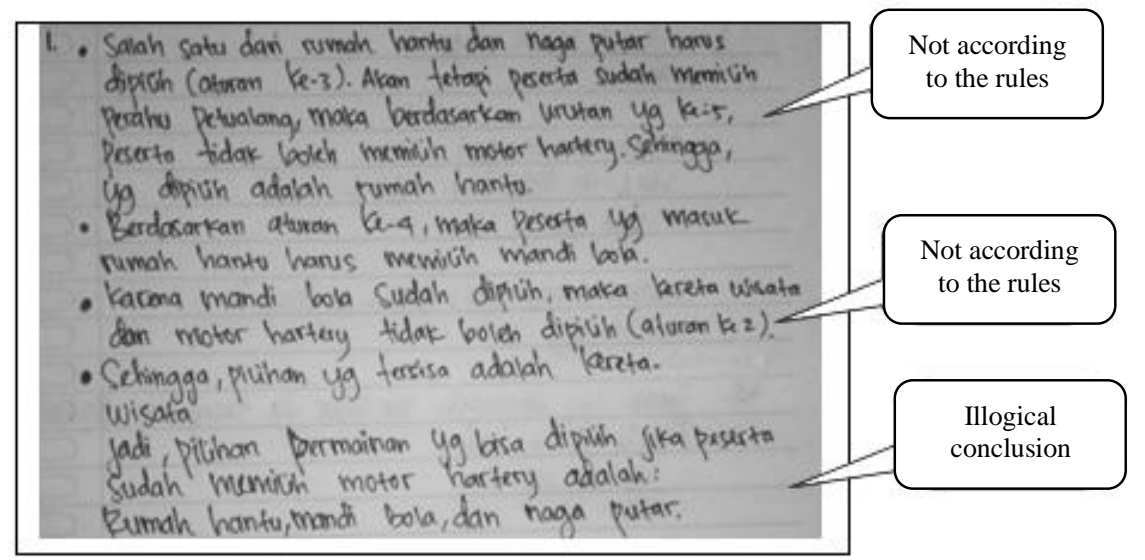

Figure 2. Example of students answering incorrectly No. 1

Problem number 2 is a PISA Level 3 model of mathematics, mathematical competence at this level is that students can carry out procedures well, including procedures that require sequential decisions. The indicator of mathematical reasoning in question number 2 is to use patterns and relationships to analyze mathematical situations/make analogies, generalizations. Question number 2 is "A farmer in Pulau Sari Subdistrict, Pandeglang Regency is able to cultivate a field of $900 \mathrm{~m}^{2}$ for $9 \mathrm{~h}$. If he uses a tractor it takes only $4 \mathrm{~h} 30 \mathrm{~min}$. After $1 \mathrm{~h} 30 \mathrm{~min}$ using the tractor, suddenly the machine broke down and the farmer used a hoe to continue his work. How long (minutes) will the farmer have to process it?" Figure 3 gives example of students answering correctly in question number 2.

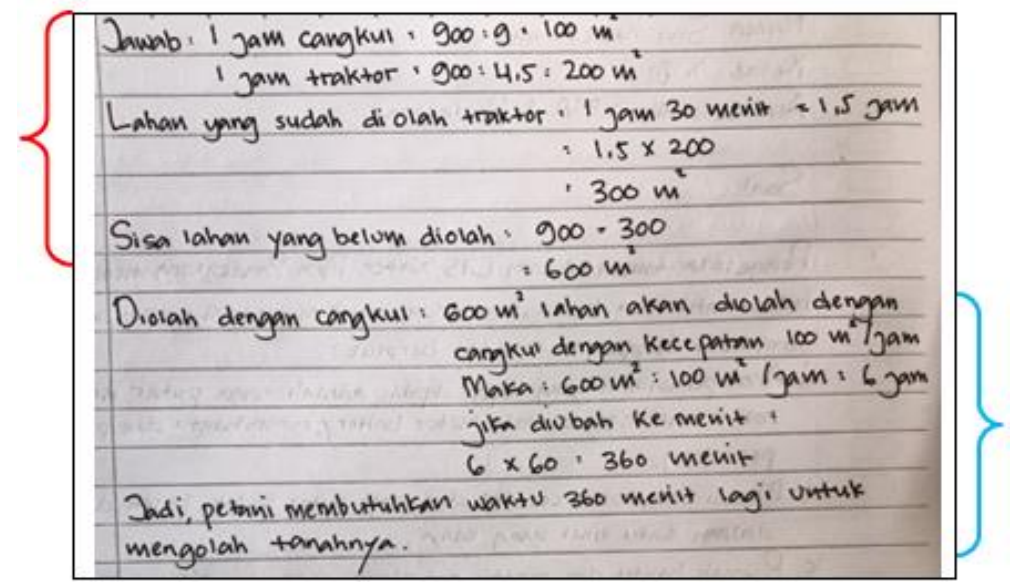

Figure 3. Example of students answering correctly No. 2

In question number 2, out of 80 students who answered correctly totaled 28 students or $35 \%$. Students can reason well by using patterns and relationships to analyze situations that have been implicitly listed in the question, which can be seen in Figure 3 with a red mark. Then, students make analogies and make generalizations well too, it can be seen in Figure 3 with blue markings. In question number 2, there were students who answered incorrectly, out of 80 students 52 students answered incorrectly or $65 \%$. The mistake they made was that they did not make patterns and relationships to analyze the situation that had been included in the questions, they only wrote down what they knew in the questions. Then immediately answered with reason that $1 \mathrm{~h} 30 \mathrm{~min}$ had been used so there was only 9 hleft. Though $9 \mathrm{~h}$ using a hoe to $900 \mathrm{~m}^{2}$ and $4 \mathrm{~h} 30$ min using a tractor, can be seen in Figure 4. There is also the only answer is $360 \mathrm{~min}$ without a process from which $360 \mathrm{~min}$ were obtained. There are students who answer 180 min with reasoning $1 \mathrm{~h} 30 \mathrm{~min}$ using a tractor means a total of $4 \mathrm{~h} 30 \mathrm{~min}$ reduced by the time that has been used so the remaining $3 \mathrm{~h}$, instantly reduce with time using a hoe. 


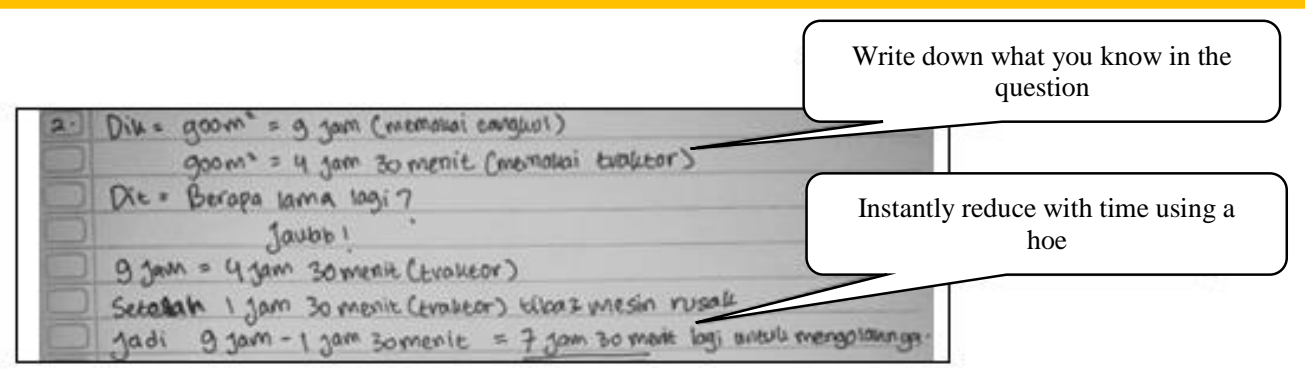

Figure 4. Example of students answering incorrectly No. 2

Question number 3 is a PISA level 4 model of mathematics, mathematical competence at this level is that students can work effectively with models in concrete but complex situations. They can select and integrate different representations, and relate them to real situations. The indicator of mathematical reasoning in question number 3 is to provide an explanation of the model, facts, properties, and relationships/patterns, to construct valid arguments. The question in number 3 is "Pak sodikin has a tank filled with oil to the brim. At first, 170 liters were taken from the tank, then 540 liters were taken and the rest were sold at a price of Rp. 300/liter and the rest actually got Rp. 87.000 and he is still 10\% profit. Then the price of 1 tank of oil is..."

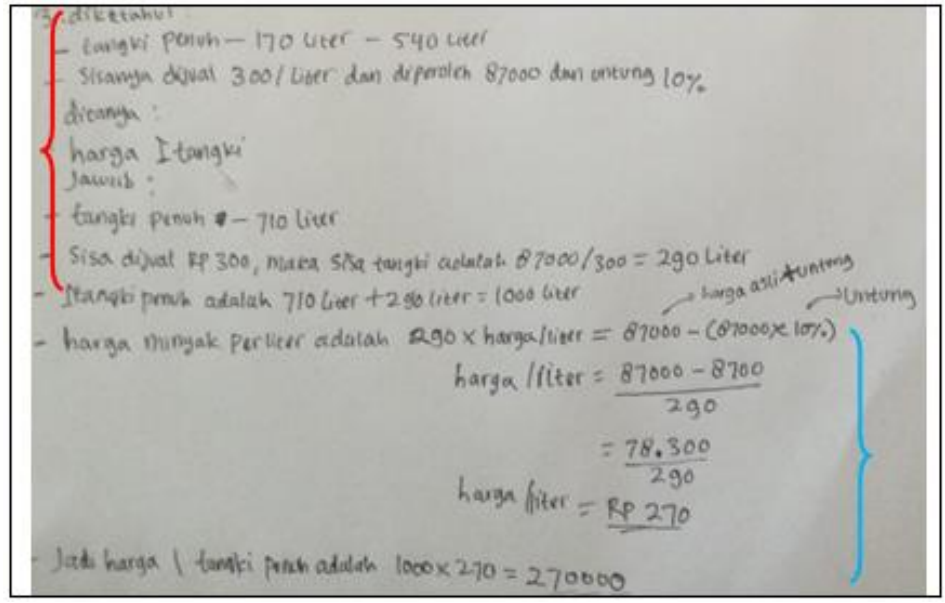

Figure 5. Example of students answering correctly No. 3

In question number 3, only 1 student answered correctly out of 80 students, so only $1 \%$ could work with the correct answer and 99\% answered incorrectly. The results of the answers of students who answered correctly can be seen in Figure 5, students first identify what is known in the problem then connect the things that are already known from the question with the results of reasoning related to the contents of the full tank how many liters, the result of a full tank is 1000 liters, can be seen in Figure 5 which is marked in red. After knowing everything from the contents of a full tank, the price per liter then students make valid arguments, which can be seen in Figure 5 marked in blue. While students answered wrong on average they answered incorrectly based on the process or argument or there was no response at all. Students only write down the numbers that are known in the question but do not know the problem being asked. Several previous studies have also shown similar case, that is in solving mathematics problems students tend to focus on computing the given number only without realizing and employing the relevant concepts which underlies the problem (Sepeng, 2013; Nasriadi \& Sari, 2018; Satiti \& Verdianingsih, 2019). Examples of students answering incorrectly can be seen in Figure 6.

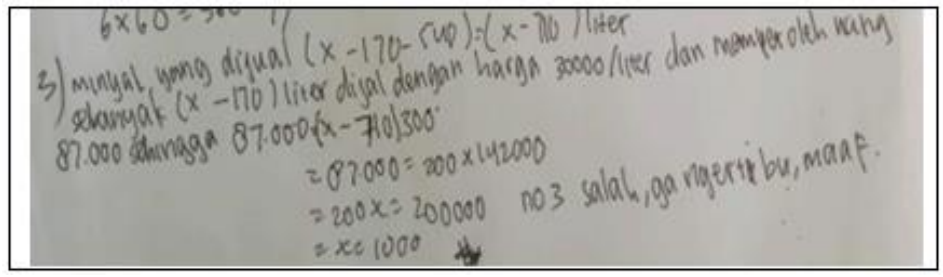

Figure 6. Example of students answering incorrectly No. 3 
Question number 4 is a math problem with the PISA level 5 model, mathematical competence at this level is that students can work with models for complex situations, know the obstacles they face, and make assumptions. The indicator of mathematical reasoning in question number 4 is compiling and studying conjectures (allegations). The question in question number 4 is "A car can travel through cities $\mathrm{A}$ and $\mathrm{B}$ at a speed of $60 \mathrm{~km} / \mathrm{h}$ in $4 \mathrm{~h}$ and consumes 1 liter of fuel for every $10 \mathrm{~km}$. If the car is traveling at $80 \mathrm{~km} / \mathrm{h}$ and the distance is more than $100 \mathrm{~km}$, then the car will use $10 \%$ more fuel compared to 60 $\mathrm{km} / \mathrm{h}$. The car has been filled with 10 liters of fuel and if refilling takes $10 \mathrm{~min}$. How long will it take the car to reach its destination at $80 \mathrm{~km} / \mathrm{h}$ ?

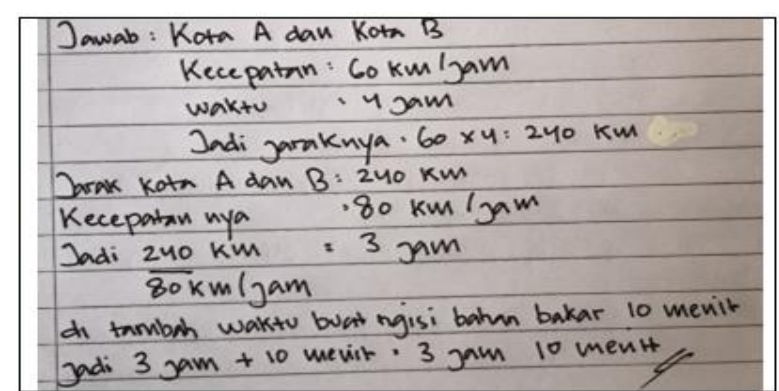

Figure 7. Example of students answering correctly No. 4

In question number 4 , students answered correctly out of 80 only 2 students or $3 \%$ answered correctly. Figure 7, an example of students answering correctly number 4, students answering with reasoning ability, compiling and reviewing conjectures are good. This student knows what is being asked and the answer key regarding time is understood. This student's reasoning has been running well if the speed is $80 \mathrm{~km} / \mathrm{h}$ then the distance from city A to B is $240 \mathrm{~km}$ then the time it takes is $3 \mathrm{~h}$. In the problem, it is clear that if the car has a speed of $80 \mathrm{~km} / \mathrm{h}$ and the distance traveled is more than $100 \mathrm{~km}$, the car will use $10 \%$ more fuel compared to the speed of $60 \mathrm{~km} / \mathrm{h}$, meaning the car will stop to fill up with gasoline. So students directly add the known time $3 \mathrm{~h}+10 \mathrm{~min}$ to fill up with gas $=3 \mathrm{~h} 10 \mathrm{~min}$. The students who answered incorrectly were $97 \%$. The average error that answered incorrectly was that part of the answer was incomplete but contained one correct argument and the answer was incorrect based on the process or there was no response at all. Figure 8 shows an example of a student answering number 4.

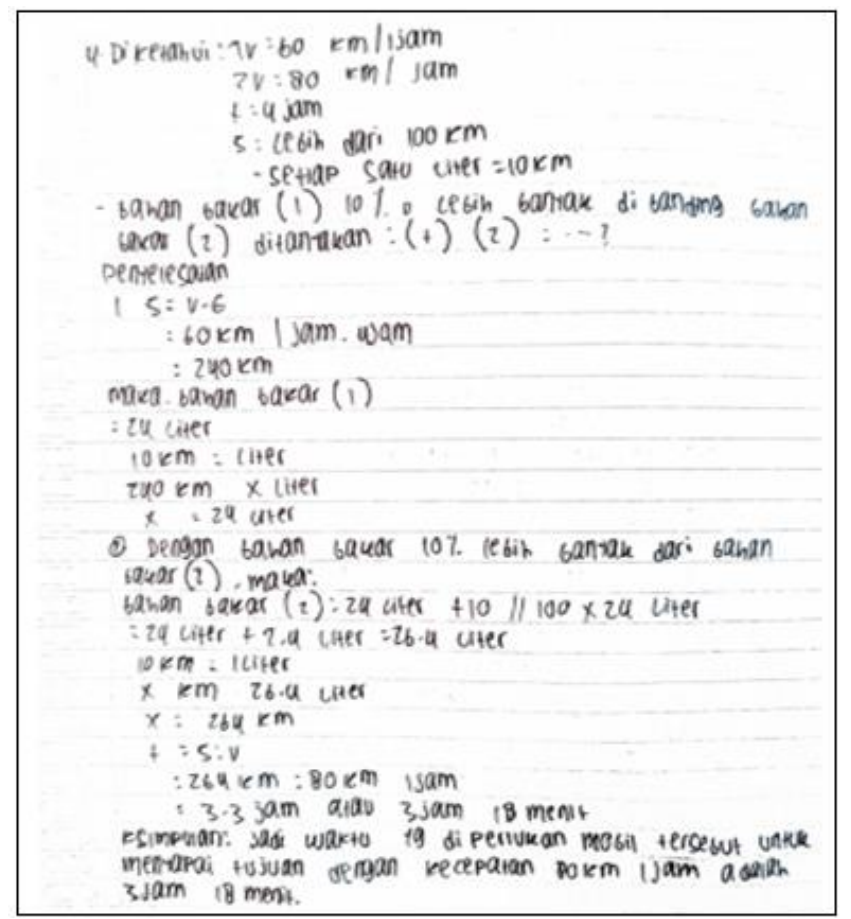

Figure 8. Example of students answering incorrectly No. 4 


\section{Discussion}

This study aims to determine the mathematical reasoning ability of students in Pandeglang Regency in solving post-Covid-19 PISA model math problems. Based on the research results that have been stated and based on the percentage results from Table 5, the following is a detailed discussion of each indicator of mathematical reasoning ability in solving PISA model math problems.

\section{Mathematical reasoning indicator on question number 1 (PISA Level 2)}

Based on the results of the answer analysis, students' mathematical reasoning abilities on PISA level 2 math problems with a percentage per indicator of 55\% and according to the criteria in Table 4 . It can be concluded that the reasoning abilities of Pandeglang Regency High School students post covid 19 are fair in following inference rules, checking validity argument, prove and draw logical conclusions. This is in accordance with the results of interviews with class $\mathrm{X}$ mathematics teachers from the two schools that were used as research sites. The following are the results of the researcher's interview with the two mathematics teachers at different times and places. The researcher used the initials of teacher A (Mathematics Teacher at SMAN 1 Pandeglang) and teacher B (Mathematics Teacher at SMAN 2 Pandeglang).

Researcher : How is the mathematical reasoning ability of students in class $\mathrm{X}$ at this time, especially graduates of online learning outcomes for the 2020/2021 school year?

Teacher A : Overall it is poor, but there are some reasoning indicators that they can follow/can answer well, namely drawing conclusions if there are data or rules that have been included in the questions.

Teacher B : Their ability is still poor, but for simple reasoning questions they can still answer well.

PISA Level 2 Model Mathematical Problems when associated with Bloom's taxonomic thinking level in the discussion of the results of the study according to Setiawan et al. (2014) Pandeglang Regency High School students' mathematical ability in terms of understanding instructions is fair but their thinking skills are at the low order thinking level so that according to the results of this study, students when faced with simple reasoning problems on average they will be able to answer correctly.

Students' understanding ability is a basic ability that students must have for skills inference rules, checking validity argument, prove and draw logical conclusions. Students cannot develop their reasoning abilities if they do not understand the material being studied (Hikmah, 2017). In other studies, by having good argumentative skills, it can improve students' cognitive abilities, especially in the aspect of understanding (Kuhn, 2010) and also train higher-order thinking skills (Akarsu et al., 2013), especially in reasoning skills.

\section{Mathematical reasoning indicator on question number 2 (PISA Level 3)}

Based on the results of the answer analysis, students' mathematical reasoning abilities on PISA level 3 math problems with a percentage per indicator of 52\% and according to the criteria in Table 4. It can be concluded that the mathematical reasoning abilities of Pandeglang High School students after Covid-19 are fair in using patterns and relationships to analyze mathematical situations/make analogies, generalizations. This is a benchmark that high school students in Pandeglang Regency after Covid-19 can solve problems in daily life related to patterns, relationships, analyze situations, make analogies and conclude. Of the 80 students who were the subjects of this study, only 28 students answered correctly or $35 \%$. This further supports the fact that the average student in Indonesia can only work on PISA model questions level 3 and below (OECD, 2019).

Some factors that Indonesian students can not work on PISA questions, one of them is mathematics learning in each school, there is a difference in treatment. Schools in cities, many mathematics teachers have good cognitive knowledge and knowledge of learning technology and school facilities are very good in the online learning process during Covid-19. Meanwhile in regional schools, some mathematics teachers have good cognitive knowledge skills but poor of knowledge of learning technology, because facilities in schools or internet networks in the area are very poor in the online 
learning process. The quality of students is strongly influenced by several aspects, one of which is a good quality teacher. The advancement of a country's education can be seen from good quality teachers and good student performance can contribute to the improvement of the overall learning environment and the future of the student it is raised (Meroni et al., 2015).

\section{Mathematical reasoning indicator on question number 3 (PISA Level 4)}

Based on the results of the answer analysis, students' mathematical reasoning abilities on PISA level 4 math problems with a percentage per indicator of $12 \%$ and according to the criteria in Table 4. It can be concluded that the mathematical reasoning abilities of Pandeglang High School students after Covid-19 are very poor in providing explanations to the model, facts, traits, and relationships/patterns, compose valid arguments. According to the results of interviews with mathematics teachers of both schools (SMAN 1 Padeglang and SMAN 2 Pandeglang) at different times and places.

Researcher : So, for more complex reasoning questions they can't answer?

Teacher A : Mostly yes, there are only a few students / only a few can answer if given a difficult question, so the reasoning is still poor.

Teacher B : For current students, judging from the daily exams, if they are given story questions, which of course require reasoning skills, for story questions that are more complex/difficult, yes, poor. Maybe there are only a few students who can answer correctly, because they are not familiar with story questions related to reasoning, this 2 years range is indeed being applied by the minister of education to mathematics teachers to use PISA, mathematical literacy, HOTS questions. When last year during the pandemic they in 9th grade junior high school did online learning, on average they were only given tasks by math teachers with various conditions of junior high school in Pandeglang Regency whose abilities/conditions were uneven.

The explanation from teacher B stated that when students were in junior high school, they did not learn mathematics optimally because it was done online, and there were many obstacles. Whereas when students are at that level, it is a very effective age range to improve mathematical reasoning abilities. Thus, teachers should be aware of this opportunity and actively search for means to boost students' reasoning skills during those years through their school subjects (Vo \& Csapo, 2020).

From these results, it shows that students have difficulty in solving math problems using the PISA Level 4 model, according to the results of research from Simalango et al. (2018) that the most difficulty experienced by students in solving PISA questions at level 4 which requires students to be able to identify information and turn it into a simple mathematical model. At level 4, out of 80 students there was only 1 student who answered correctly.

\section{Mathematical reasoning indicator on question number 4 (PISA Level 5)}

Based on the results of the answer analysis, students' mathematical reasoning abilities on PISA level 4 math problems with a percentage per indicator of $16 \%$ and according to the criteria in Table 4. It can be concluded that the mathematical reasoning abilities of Pandeglang High School students after Covid-19 are very poor in compiling and studying conjectures (allegedly). This is in accordance with the results of PISA in 2012 which stated that for PISA level 5 and level 6 questions, none of the Indonesian students was able to answer (OECD, 2013). Out of 80 students only 2 students could answer correctly. According to Dasaprawira et al. (2019) students who have difficulty in answering these questions, because they are still not accustomed to students working on problems that are contextual and creative thinking in which if ordinary students are only given formal lessons such as those in textbooks. Therefore, students' reasoning ability is very poor.

Overall, data from the results of students' reasoning ability tests and interviews with mathematics subject teachers stated that, after Covid, students' mathematical abilities, especially reasoning, were poor. According to the mathematics teacher before Covid 19, the reasoning ability of students was not too bad because there were still some students who could answer well and correctly. Teachers can find out students' difficulties and provide solutions directly and the learning process in the classroom can be controlled properly. However, when online learning was implemented the results were only one or two 
students who could answer. This is because teachers and students experience many obstacles, both in terms of material delivery techniques, as well as technical means of infrastructure such as signal interference. This online learning is not very effective for students who have medium to lower cognitive abilities, they really need extra guidance, while for students with high cognitive abilities they can follow well because they are used to self-study. The fact in the field that most students are in lower-middle cognitive abilities so to solve complex daily problems they have difficulties, this illustrates that the condition of high school students in Pandeglang Regency has the ability to make decisions in their daily problems is poor.

\section{CONCLUSION}

Based on the results of the research and discussion, it can be concluded that in general the mathematical reasoning ability of Pandeglang Regency High School students using the PISA PostCovid-19 model of mathematics is poor. This illustrates that the condition of high school students in Pandeglang Regency has poor ability to make decisions in their daily problems. In detail related to the mathematical reasoning abilities of Pandeglang Regency High School students after Covid-19 using the PISA model of mathematics questions, namely 1) the students' reasoning ability is fair in following the rules of inference, checking the validity of arguments, proving and drawing logical conclusions; 2) students' mathematical reasoning ability is fair in using patterns and relationships to analyze mathematical situations/make analogies, generalizations; 3) students' mathematical reasoning ability is very poor in providing explanations of models, facts, traits, and relationships/patterns, compiling valid arguments; 4) students' mathematical reasoning ability is very poor in compiling and studying conjectures (allegations).

\section{ACKNOWLEDGMENT}

The research was fully funded by the Directorate of Research and Community Service of The Ministry of Research and Technology/National Research and Innovation Agency in through the PDP scheme in 2021.

\section{REFERENCES}

Agustyaningrum, N., Hanggara, Y., Husna, A., Abadi, A. M., \& Mahmudii, A. (2019). An analysis of students' mathematical reasoning ability on abstract algebra course. International Journal of Scientific and Technology Research, 8(12), 2800-2805. http://www.ijstr.org/finalprint/dec2019/An-Analysis-Of-Students-Mathematical-Reasoning-Ability-On-Abstract-AlgebraCourse.pdf

Akarsu, Bayram, Kadriye Bayram, Josip Slisko, A. C. C. (2013). Understanding elementary students' argumentation skil discrepant event students' argumentation skills through discrepant event "marbles in the jar." SSRN Electronic Journal, 6(3), 221-232. https://www.researchgate.net/publication/349412517_Understanding_Elementary_Students\%27_ Argumentation_Skills_through_Discrepant_Event_Marbles_in_the_Jar

Akbar, J. (2020). Perjalanan pandemi Covid-19 di Indonesia, lebih dari 100.000 kasus dalam 5 bulan [The journey of the Covid-19 pandemic in Indonesia, more than 100,000 cases in 5 months]. Kompas,(August 3, 2020). https://www.kompas.com/

Ambarita, S. M., Asri, L., Agustina, A., Octavianty, D., \& Zulkardi. (2018). Mathematical modeling skills on solving PISA problems. Journal of Physics: Conference Series, 1097(1). 1-7 https://doi.org/10.1088/1742-6596/1097/1/012115

Anisah, Zulkardi, \& Darmawiyono (2011). Pengembangan soal matematika model PISA pada konten quantity untuk mengukur [Development of PISA model math problems on quantity content to measure]. Jurnal Pendidikan Matematika Universitas Sriwijaya, Palembang Indonesia, 5(1), 115. https://doi.org/10.22342/jpm.5.1.333.

Arikunto, S., \& Jabar, A., S., C. (2018). Evaluasi program pendidikan pedoman teoretis praktis bagi mahasiswa dan praktis pendidik edisi kedua [Evaluation of educational programs practical theoretical guidelines for students and practical educators second edition]. Jakarta: Bumi Aksara. 
Ayal, C. S., Kesuma, Y. S., Sabandar, J., \& Dahlan, J. A. (2016). The enhancement of mathematical reasoning ability of junior high school students by applying mind mapping strategy. Journal of Education and Practice, 7(25), 50-58. https://eric.ed.gov/?id=EJ1115860

Basra, M \& Fauzi, Kms, M, A. (2017). An analysis of students, mathematical reasoning ability using metacognitive strategy based-learning in malay culture among junior high school students. Journal of Education and Practice, 8(21), 87-92. https://www.iiste.org/Journals/index.php/JEP/article/view/37933

Dasaprawira, M.N., Zulkardi, \& Susanti, E. (2019). Developing mathematics questions of PISA type using Bangka context. Journal on Mathematics Education, 10(2), 303-314. https://doi.org/10.22342/jme.10.2.5366.303-314

Ginting, S. M., Prahmana, I. C. R., Isa, M \& Murni, M. (2018). Improving the reasoning ability of elementary school student through the Indonesian realistic mathematics education. Journal on Mathematics Education, 9(1), 41-53. https://doi.org/10.22342/jme.9.1.5049.41-54

Harususilo, Y. E. (2019). Skor PISA 2018: daftar peringkat kemampuan matematika, berapa rapor Indonesia? [PISA 2018 score: list of math ability rankings, how much is Indonesia's report card?]. Kompas. Com, 7. https://edukasi.kompas.com/

Hasanah, S. I., Tafrilyanto, C. F., \& Aini, Y. (2019). Mathematical reasoning: The characteristics of students' mathematical abi lities in problem solving. Journal of Physics: Conference Series, 1188(1), 1-8. https://doi.org/10.1088/1742-6596/1188/1/012057

Hikmah, R. (2017). Penerapan model advance organizer untuk meningkatkan kemampuan pemahaman siswa [Application of advance organizer model to improve students' understanding ability]. SAP (Susunan Artikel Pendidikan), 1(3), 271-280. https://doi.org/10.30998/sap.v1i3.1204

Kuhn, D. (2010). Teaching and learning science as argument. Science Education, 94(5), 810-824. https://doi.org/10.1002/sce.20395

Linda. (2020). Upaya meningkatkan hasil belajar mahasiswa pgmi semester iii Stai Syekh Manshur pada mata kuliah matematika ii melalui model pembelajaran kooperatif tipe two stay two stray [Efforts to improve student learning outcomes of PGMI semester III Stai Syekh Manshur in Mathematics II courses through the cooperative learning model type two stay two stray]. Jurnal Cakrawala Pedagogik, 4(1), 91-98. https://doi.org/10.51499/cp.v4i1.144

Manalu, H., Simamora, R., \& Hidayat, F. A. (2020). Kemampuan penalaran matematis siswa laki-laki dan perempuan dalam menyelesaikan soal PISA konten change and relationships [Mathematical reasoning ability of male and female students in solving PISA questions content change and relationships]. PHI: Jurnal Pendidikan Matematika, 4(1), 16-20. http://phi.unbari.ac.id/index.php/phi/article/view/81/64

Meroni, E. C., Vera-Toscano, E., \& Costa, P. (2015). Can low skill teachers make good students? empirical evidence from PIAAC and PISA. Journal of Policy Modeling, 37(2), 308-323. https://doi.org/10.1016/j.jpolmod.2015.02.006

Nasriadi, A., \& Sari, I. K. (2018). Kemampuan siswa memecahkan soal setara PISA konteks pekerjaan: studi pengembangan soal PISA konten change and relationship [Students' ability to solve problems equivalent to PISA work context: a study of the development of PISA questions content change and relationship]. Jurnal Pendidikan Matematika RAFA, 3(2), 223-238. https://doi.org/10.19109/jpmrafa.v3i2.1744

NCTM. (2000). Principles and standards for school mathematics. United States of America: The National Council of Teachers of Mathematics.

OECD. (2013). PISA 2012 assessment and analytical framework: mathematics, reading, science, problem solving and financial literacy. Paris: OECD Publishing. http://dx.doi.org/10.1787/9789264190511-en

OECD. (2014). PISA 2012 result in focus: what 15-year-olds know and what they can do with what they 
know. Paris: OECD Publishing. https://www.oecd.org/pisa/keyfindings/pisa-2012-resultsoverview.pdf

OECD. (2019). PISA 2018 result combined executive summaries volume I, II, \& III. Paris: OECD Publishing. https://www.oecd.org/pisa/Combined_Executive_Summaries_PISA_2018.pdf

Satiti, W. S., \& Verdianingsih, E. (2019). Penggunaan scaffolding untuk mengatasi kesulitan problem solving mahasiswa calon guru [The use of scaffolding to overcome the problem solving difficulties of prospective teacher students]. JMPM: Jurnal Matematika dan Pendidikan Matematika, 4(2), 113-127. http://journal.unipdu.ac.id:8080/index.php/jmpm/article/view/1680

Sepeng, P. (2013). Use of unrealistic contexts and meaning in word problem solving: A case of second language learners in township schools. International Journal of Research in Mathematics, 1(1), 814.https://www.researchgate.net/publication/258319165_use_of_unrealistic_contexts_and_meani ng_in_word_problem_solving_a_case_of_second_language_learners_in_township_schools

Setiawan, H., Dafik, \& Lestari, N. D. S. (2014). Soal matematika dalam PISA kaitannya dengan literasi matematika dan keterampilan berfikir tingkat tinggi [Math problems in PISA, its relation to mathematical literacy and higher-order thinking skills]. Prosiding Seminar Nasional Matematika, November, 244-251. https://jurnal.unej.ac.id/index.php/psmp/article/view/955

Simalango, M. M., Darmawijoyo, \& Aisyah, N. (2018). Analisis kesulitan siswa dalam menyelesaikan soal-soal PISA tahun 2012 level 4, 5, dan 6 di SMP N 1 Indralaya [Analysis of students' difficulties in solving PISA questions at levels 4, 5, and 6 at SMP N 1 Indralaya.]. Jurnal Pendidikan Matematika, 12(2), 43-58. https://ejournal.unsri.ac.id/index.php/jpm/article/view/4246

Sulistiawati. (2014). Analisis kesulitan belajar kemampuan penalaran matematis siswa pada materi luas permukaan dan volume limas [Analysis of learning difficulties of students' mathematical reasoning abilities on the surface area and volume of pyramids]. Proceding Seminar Nasioanal Pendidikan Matematika, Sains, dan TIK STKIP Surya 2014, 205-225. https://www.researchgate.net/publication/274140345_analisis_kesulitan_belajar_kemampuan_pe nalaran_matematis_siswa_smp_pada_limas

Sunardi \& Muslimin. (2019). Analisis kemampuan penalaran matematika siswa SMA pada materi geometri ruang [Analysis of high school students' mathematical reasoning abilities on spatial geometry material]. Kreano, Jurnal Matematika Kreatif-Inovatif, 10(2), 171-178. https://doi.org/10.15294/kreano.v10i2.18323

Usnul, U., Johar, R., \& Sofyan, H. (2019). Potential effect of PISA equivalent questions using the context of Aceh traditional houses. JRAMathEdu (Journal of Research and Advances in Mathematics Education), 4(2), 89-100. https://doi.org/10.23917/jramathedu.v4i2.8362

Vo, D.V., \& Csapo, B. (2020). Development of inductive reasoning in students across school grade levels. Thinking Skills and Creativity, 37(July) 1-15. https://doi.org/10.1016/j.tsc.2020.100699

Wahyuni, E. S., Susanto, \& Hadi, A. F. (2019). Profile of the student's mathematical reasoning ability in solving geometry problem. Journal of Physics: Conference Series, 1211(1) 1-9. https://doi.org/10.1088/1742-6596/1211/1/012079 